Politics on the Edges of Liberalism 



\section{Politics on the Edges of Liberalism}

Difference, Populism, Revolution, Agitation

Benjamin Arditi 
(C) Benjamin Arditi, 2007

Edinburgh University Press Ltd

22 George Square, Edinburgh

Typeset in Io/I 3 pt Sabon by

TechBooks, New Delhi, India, and

printed and bound in Great Britain by

Cromwell Press, Trowbridge, Wilts

A CIP record for this book is available from the British Library

ISBN 978 ○ 748625 I I 6 (hardback)

The right of Benjamin Arditi to be identified as author of this work has been asserted in accordance with the Copyright, Designs and Patents Act I988. 